University of Nebraska - Lincoln

DigitalCommons@University of Nebraska - Lincoln

Drought Mitigation Center Faculty Publications Drought - National Drought Mitigation Center

2002

\title{
Spatial Representation of Agroclimatology in a Study of Agricultural Drought
}

Olga V. Wilhelmi

NCAR, olgaw@ucar.edu

Kenneth Hubbard

University of Nebraska - Lincoln, khubbard1@unl.edu

Donald A. Wilhite

University of Nebraska - Lincoln, dwilhite2@unl.edu

Follow this and additional works at: https://digitalcommons.unl.edu/droughtfacpub

Part of the Climate Commons

Wilhelmi, Olga V.; Hubbard, Kenneth; and Wilhite, Donald A., "Spatial Representation of Agroclimatology in a Study of Agricultural Drought" (2002). Drought Mitigation Center Faculty Publications. 10.

https://digitalcommons.unl.edu/droughtfacpub/10

This Article is brought to you for free and open access by the Drought - National Drought Mitigation Center at DigitalCommons@University of Nebraska - Lincoln. It has been accepted for inclusion in Drought Mitigation Center Faculty Publications by an authorized administrator of DigitalCommons@University of Nebraska - Lincoln. 
Published in International Journal of Climatology 22 (2002), pp. 1399-1414; doi: 10.1002/joc.796 Copyright (C) 2002

Royal Meteorological Society; published by John Wiley \& Sons. Used by permission.

Submitted March 26, 2001; revised March 14, 2002; accepted March 15, 2002.

\title{
Spatial Representation of Agroclimatology in a Study of Agricultural Drought
}

\author{
Olga V. Wilhelmi, Environmental and Societal Impacts Group, \\ National Center for Atmospheric Research, Boulder, CO 80307-3000, USA \\ Kenneth G. Hubbard, High Plains Regional Climate Center, \\ University of Nebraska-Lincoln, Lincoln, NE 68583-0728, USA \\ Donald A. Wilhite, National Drought Mitigation Center, \\ University of Nebraska-Lincoln, Lincoln, NE 68583-0728, USA \\ Corresponding author - Olga V. Wilhelmi, NCAR, PO Box 3000, \\ Boulder, Colorado 80307-3000, USA; email olgaw@ucar.edu
}

\begin{abstract}
Agricultural drought is the leading cause for crop failure throughout the world. In the USA, significant impacts of recent droughts on agricultural production indicate the continuing vulnerability of the country to drought. This paper presents a methodology for spatial representation of the agroclimatic component of agricultural drought vulnerability. This methodology was developed as a part of an integrated assessment of drought vulnerability. For the spatial analysis, the state of Nebraska was selected as a study area because of the considerable variation in climatology, soil characteristics, land use, and cropping patterns. The underlying approach assumes that the best spatial characterization of the state's agroclimatology from the agricultural drought vulnerability perspective is the probability of seasonal crop moisture deficiency. Seasonal crop water-use thresholds for well-watered crops (e.g. corn, soybean, and sorghum) were estimated using the evapotranspiration (ET) mathematical model. For wheat and grass, ET values were estimated based on the relationship between ET, water-use efficiency, and crop yield. Historical grain yield data were analyzed to define an economically viable threshold for wheat. Seasonal ET thresholds determined for the crops were used to calculate area-weighted mean ET for the combination of crops in every county. The threshold values and long-term precipitation data were used for calculating statistical probabilities of seasonal crop moisture deficiency. Probability values were analyzed at 112 weather stations across Nebraska, spatially interpolated and classified using geographic information systems. The spatial pattern of probabilities of seasonal crop moisture deficiency reflected both seasonal precipitation across Nebraska and the distribution of crops and grasses.
\end{abstract}

Keywords: agroclimatology, drought, geographic information systems, spatial analysis, probability, Nebraska, precipitation, evapotranspiration

\section{Introduction}

Agricultural drought is a complex phenomenon. It links meteorological drought and soil moisture deficits to impacts on crop and forage yields, and on livestock production (Wilhite and Glantz, 1987). Drought is the leading cause of crop failure in the USA and other countries. In the last two decades, losses from drought events have significantly increased without documented evidence of an increased number of droughts, which suggests a trend of increasing vulnerability to drought in the USA (Wilhite, 2000). In 1995, the United States Federal Emergency Management Agency published the National Mitigation Strategy, which estimated the annual loss from drought in the USA at \$6-8 billion (\$6.7-8.9 billion, in 2000 dollars). Despite improvements in crop and livestock breeding, irrigation systems, tillage practices, and new or emerging technologies, case studies of recent droughts in the USA (Riebsame et al., 1991; Wilhite and Vanyarkho, 2000) have demonstrated that extended periods of precipitation deficiency continue to result in significant impacts on agricultural production. These impacts have serious economic, environmental, and social implications for agricultural producers at local and regional scales. 
The risk of agricultural drought is a product of both exposure to the hazard (e.g. climatology) and the vulnerability of cropping practices to drought conditions (Wilhite, 2000). Exposure to the hazard will vary from year to year, although over a long time frame it remains relatively steady, since drought is a normal part of climate. Vulnerability to drought is dynamic, and is the result of land use and management, farm policies, and many other factors. Up to the present time, more effort has been directed at understanding the drought hazard than at understanding drought vulnerabilities (Downing and Bakker, 2000). The term vulnerability has many definitions. Most of them contain a common thread that refers to the degree of susceptibility of society to a hazard, which could vary either as a result of variable exposure to the hazard, or because of coping abilities, or both.

In the drought vulnerability assessment studies found in the literature, climate was considered as an important component. In those assessments, the following variables were used to represent climatology: normal seasonal rainfall (Thiruvengadachari and Gopalkrishna, 1993), annual mean and standard deviation of rainfall (Ramachandran and Eastman, 1997), and long-term coefficient of variation of rainfall (Ramachandran, 1997). Drought studies often use drought indices, which reflect the effects of near-real-time weather or short-term climatological conditions for a set time period. There are several major indices that indicate how much precipitation for a given period of time has deviated from historically established norms, and some are better suited than others for certain applications. For example, the Palmer drought severity index (PDSI) (Palmer, 1965) has historically been used by the US Department of Agriculture to determine when to grant emergency drought assistance, but the PDSI performs better when working with large areas of uniform topography. Western states in the USA, with mountainous terrain and the resulting complex regional microclimates, find it useful to supplement PDSI values with other indices, such as the surface water supply index (Shafer and Dezman, 1982). The National Drought Mitigation Center is using a newer index, the standardized precipitation index (McKee et al., 1993), to monitor moisture supply conditions. The advantages of this index are that it identifies emerging droughts months sooner than the PDSI and that it is computed on various time scales (Hayes, 1999).

These drought indices are very useful monitoring tools, but they usually fall short in drought vulnerability studies as they are based on weather and short-term climatology. These indices do not take into account spatially variable crop water requirements, which are important determinants of agricultural drought vulnerability. Since agricultural drought vulnerability largely depends on climatology, land use (e.g. crop composition), and soil water-holding capacity (Wilhelmi and Wilhite, 2002), this study focused on synthesizing crop and climate data by developing a method of climatological indication of available water for the crops grown in an area. The main goal of this study was to develop a method of representing agroclimatology in a spatial framework that can be used in a geographical information system (GIS)based agricultural drought vulnerability assessment.

\subsection{Study area}

Nebraska is located along the western edge of the central lowlands of North America and astride the Great Plains that stretch from Texas to Saskatchewan (Figure 1). The absence of mountainous barriers on the north and south greatly influences the state's exposure to polar and tropical air masses throughout the year. The Rocky Mountains form a barrier to the west that places Nebraska in a rain shadow relative to Pacific air masses. In general, the state's climate is characterized by large annual temperature variations, subhumid to semiarid conditions, high inter-annual variations in precipitation, and several prominent natural hazards (e.g. droughts, floods, tornadoes, blizzards, and hail). Evapotranspiration (ET) rates are high, and in most of the region the potential evapotranspiration $\left(\mathrm{ET}_{\mathrm{p}}\right.$ ) exceeds precipitation (Wilhite, 1981). Several climatic gradients mainly determine the state's environmental and land-use characteristics: a southeast-to-northwest decrease in mean temperatures, an east-to-west decrease in precipitation, and an eastto-west increase in the $\mathrm{ET}_{\mathrm{p}}$. Agricultural settlement proceeded from east to west - down the precipitation gradient toward increasingly risky, marginal environments (Riebsame et al., 1991). Droughts of various geographic extent, severity, and duration are a recurring feature of the Nebraska climate (Wilhite, 1981, 2000; Stockton and Meko, 1983; Woodhouse and Overpeck, 1998). 


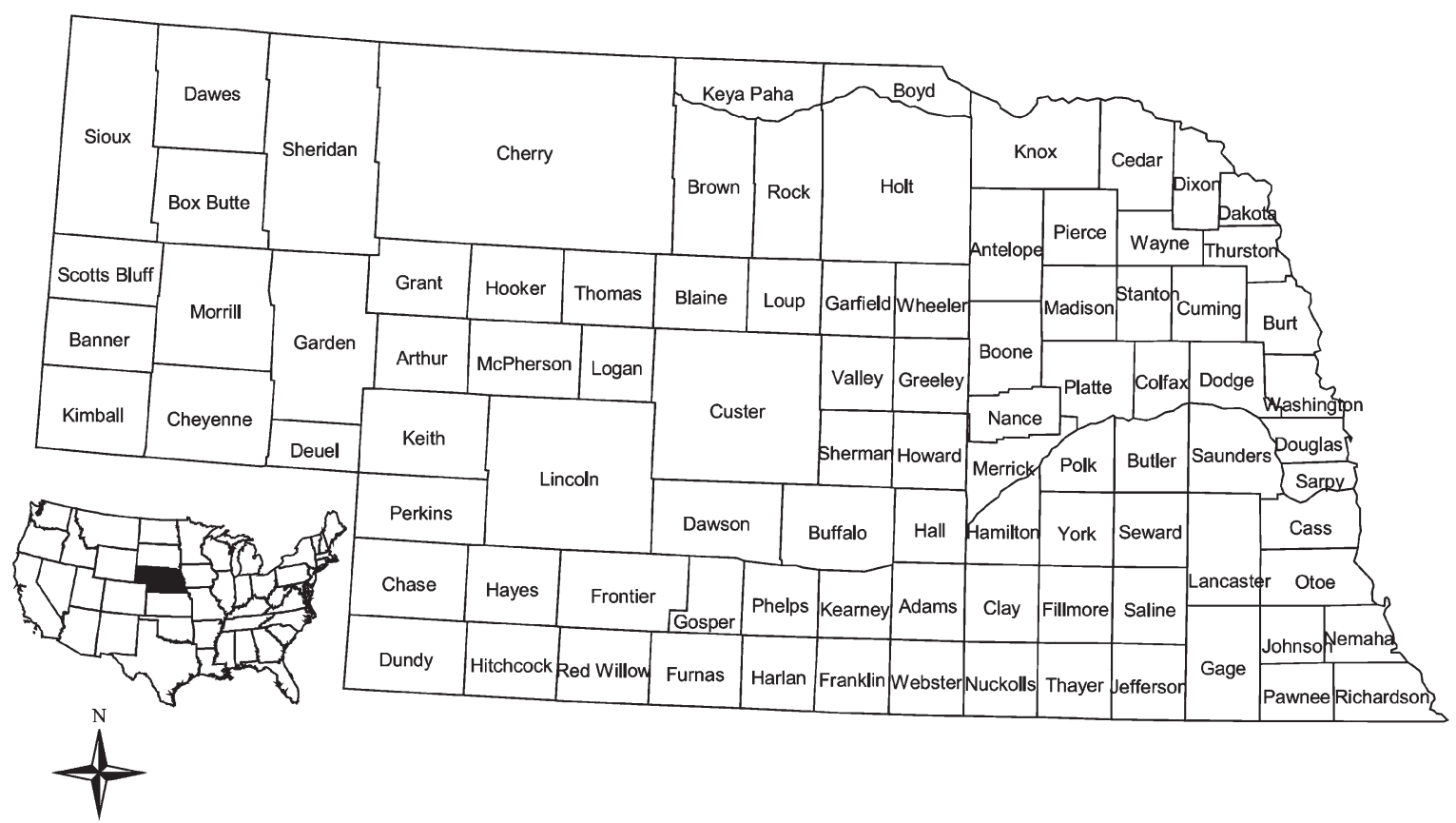

Figure 1. Study area: State of Nebraska and counties

The primary industry of Nebraska is agriculture: farms and ranches occupy $96 \%$ of the state's total land area. The leading crops are corn, soybean, winter wheat, and sorghum. Rangeland occupies nearly $9.3 \times 106$ ha (NASS, 1997). In 1997, almost 40\% of the croplands were under irrigation.

\subsection{Formulating the approach}

A fundamental assumption underlying this study was that, in order to be useful for decision makers, the agroclimatic component of a drought vulnerability analysis should be based on those measures that correlate with drought impacts (e.g. seasonal crop water use and yield reduction). A new approach for representation of agroclimatology was formulated by considering the following four key issues.

First, water availability is the factor most critical in determining plant survival, development, and ultimate productivity (Rosenberg et al., 1983). Many studies have illustrated that crop yield is directly related to the availability of soil moisture during the course of a growing season (Dale and Shaw, 1965; Musick et al., 1976; Choudhury and Kumar, 1980; Retta and Hanks, 1980). For Nebraska, moisture for crops comes from precipitation and from irrigation (for about $40 \%$ of the cropland). Irrigation data were analyzed as an independent vulnerability factor (Wilhelmi and Wilhite, 2002) and, therefore, were not included in the analysis presented here.

Second, weather risk in agriculture is viewed as the uncertainty created in earnings due to weather variability (Changnon and Kunkel, 1999). Long-term seasonal precipitation trends (examples for two sites in western and eastern Nebraska are shown in Figure 2) demonstrate a great season-to-season variability with periodic droughts, which in turn indicate a periodic risk to crop yield, reduced production, and potential income reduction.

Third, risk and vulnerability are closely connected. Risk is a product of both the hazard and societal vulnerability. In risk assessment literature, most researchers associate risk with statistical probability of disaster, and various approaches of weather risk management rely on the use of climatological data to define statistical probabilities (Krimsky and Plough, 1988; Eastman et al., 1997; Changnon and Kunkel, 1999). In the case of agricultural drought, the disaster results from a deficiency in the available moisture in the soil. Even during drought events of short duration and low intensity, the reduction of seasonal moisture essential for plant growth and development might result in low yields and the possibility of reduced incomes. 
(a)

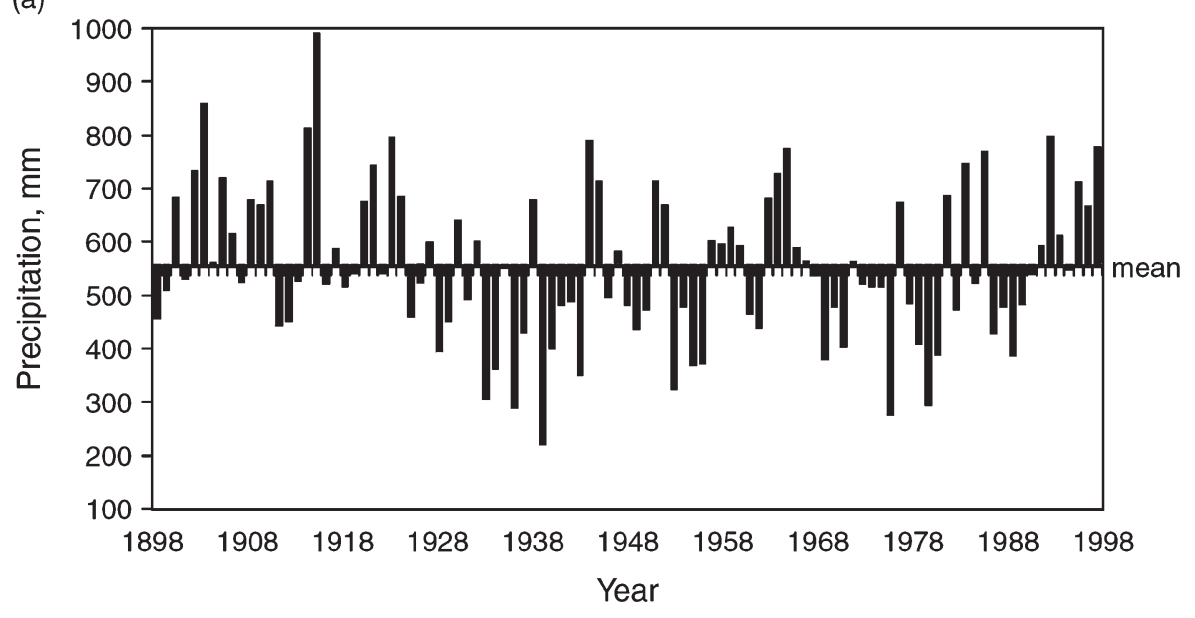

(b)

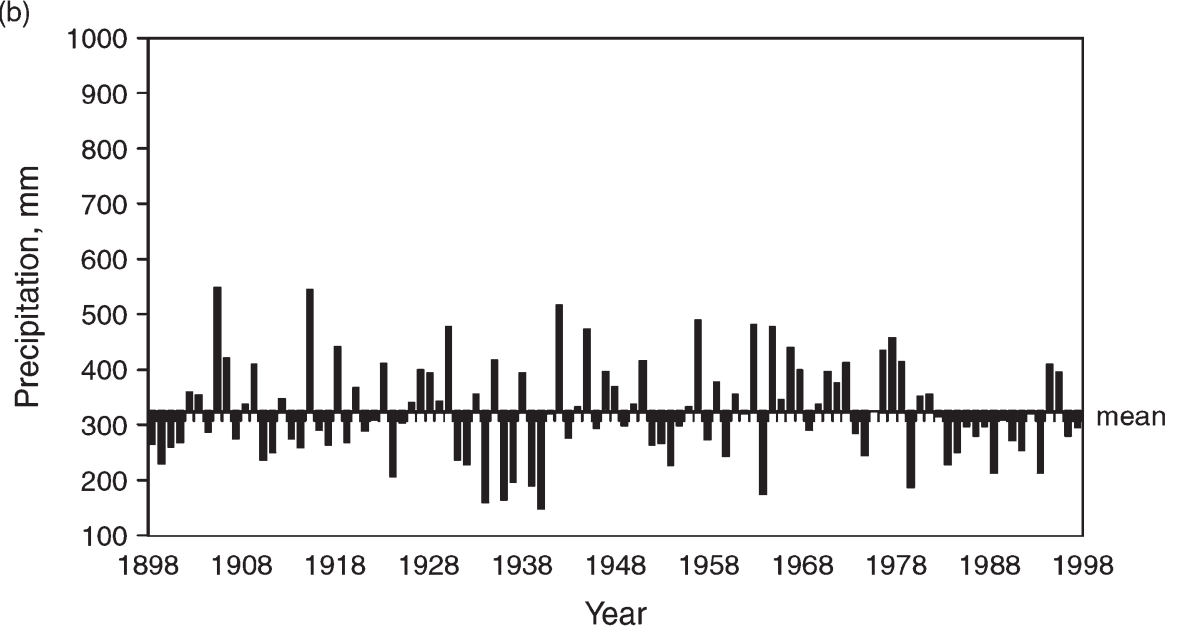

Figure 2. Seasonal (April-September) precipitation variability at two locations in Nebraska: (a) West Point; (b) Alliance (1898-1998). Data source: High Plains Regional Climate Center

Fourth, the importance of $\mathrm{ET}_{\mathrm{p}}$ in considerations of drought has been widely emphasized in the literature (Steila, 1983; Wilhite and Glantz, 1987; Rind et al., 1990; Le Houerou, 1996). The concept of ET pas introduced by both Thornthwaite (1948) and Penman (1948) and has been used in climate studies, hydrologic research, and attempts to predict water needs for dryland and irrigated agriculture (Rosenberg et al., 1983).

Based on these key issues, a fundamental assumption underlying the approach presented in this paper is that the best characterization of the climatology of the state from the agricultural drought vulnerability perspective is the probability of seasonal crop moisture deficiency. Felch (1978) states that agricultural drought begins when available stored water in the soil cannot meet the evaporative demands of the atmosphere. In order to determine the critical seasonal crop moisture thresholds for sustainable development and growth (here referred to as $\mathrm{ET}_{\mathrm{s}}$ ), seasonal crop-specific ET values were estimated.

\section{Data and Methodology}

\subsection{Data}

Several datasets were used to derive the agroclimatic component of agricultural drought vulnerability. The primary dataset was monthly precipitation data obtained from the High Plains Regional Cli- 


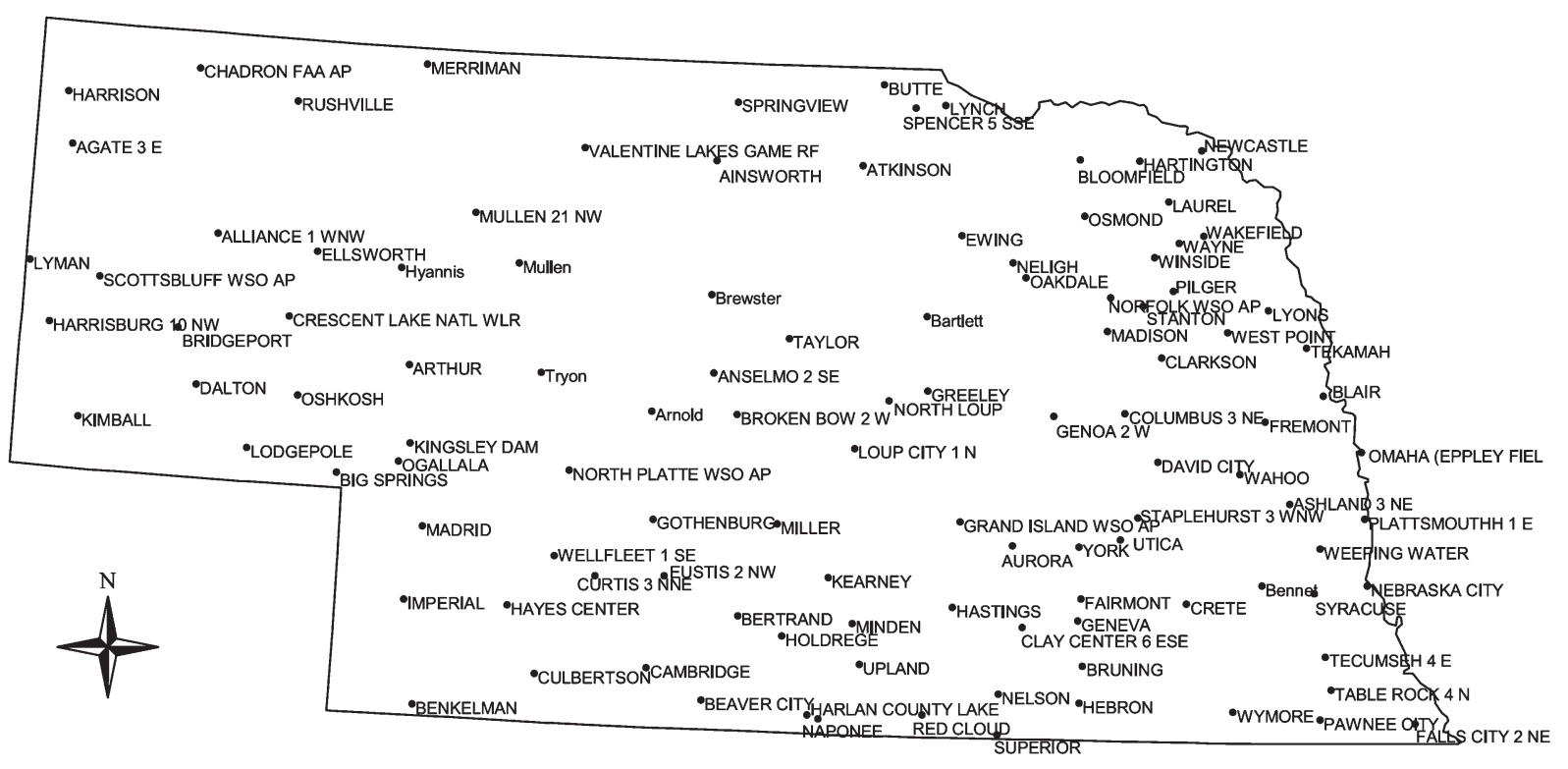

Figure 3. Locations of National Weather Service's Cooperative Observer Network weather stations used in this study

mate Center at the University of Nebraska-Lincoln. For this dataset, 112 stations were selected from across the state of Nebraska. All of these stations are part of the National Weather Service's Cooperative Observer Network (Figure 3). Precipitation data for the period from 1949 to 1998 were used in this study. Monthly data were used to calculate total precipitation for the crop's growing season from April through September. A data subset obtained from nine weather stations (Figure 4), with at least 100 years of precipitation records, was used to test statistical normality of seasonal precipitation values. The second dataset used in this study was the Agricultural Crop Statistics data reported by the Agricultural Census in 1997 (NASS, 1997). County data on average crop acreage were included in the analysis of agroclimatological factors of vulnerability. Several literature sources on Nebraska growing degreeday (GDD) regions (Neild, 1986; Aceves-Navarro, 1987; NASS, 1997), crop water-use efficiency (WUE) (Klinkebiel, 1987; Adam, 1989; Musick and Porter, 1990), and seasonal crop water use (Klocke et al., 1990) were also used to support this analysis.

\subsection{Estimating seasonal crop water-use thresholds for well-watered crops}

Seasonal crop ET rates vary among locations in Nebraska, mostly because of differences in crop water requirements over the course of the growing season and the beginning and length of the growing season. The crop's growing season begins when the temperature first becomes suitable to initiate seed germination and sustain early growth. Considering the east-to-west precipitation gradient, the southeast-to-northwest temperature gradient, and the differences in the temperature requirements for different crops grown in Nebraska, the average growing season lasts from April through to September.

Seasonal crop ET was estimated using a mathematical model developed by Hubbard (1992). The ET at Automated Weather Data Network stations was calculated by the Penman combination equation with the wind function derived by Kincaid and Hermann (1974):

$$
\mathrm{ET}_{\mathrm{p}}=\Delta\left(R_{\mathrm{n}}-G\right)+\left[\gamma f(U)\left(e_{\mathrm{s}}-e_{\mathrm{a}}\right) \div(\Delta+\gamma)\right]
$$

$R_{\mathrm{n}^{\prime}} G, f(U), e_{\mathrm{s}^{\prime}}$ and $e_{\mathrm{a}}$ are the net radiation, the soil heat flux, the wind function (at $2 \mathrm{~m}$ ), the saturated vapor pressure, and the vapor pressure of air respectively. The remaining terms in Equation (1) are the psychrometric constant $\gamma$, and the slope $\Delta$ of the saturation vapor pressure curve. 


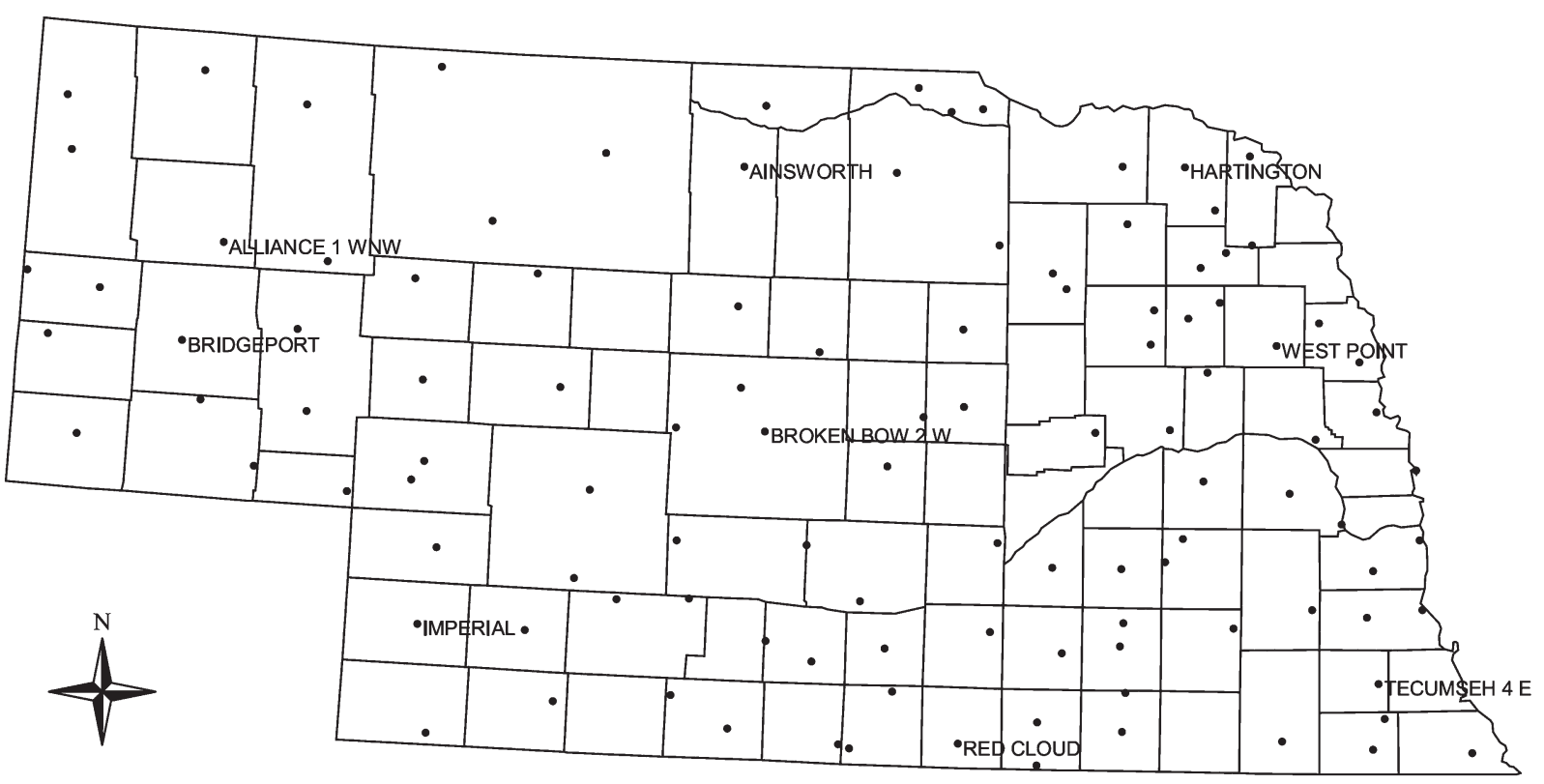

Figure 4. Locations of nine weather stations with long-term (100 years) precipitation record used for normality test

The wind function is described in Robinson and Hubbard (1990):

$$
f(U)=7.1+0.068 U
$$

when $U$ is expressed in $\mathrm{km} \mathrm{day}^{-1}$; the wind function has units of $\mathrm{MJ}\left(\mathrm{kPa} \mathrm{m}^{2} \mathrm{day}\right)^{-1}$.

Hubbard (1992) found that at rainfed sites, ET $_{\mathrm{p}^{\prime}}$ calculated using Equation (1), is an overestimate of crop water use. He suggested a modification of this method by the addition of reduction factors into the calculation of actual ET in the model, as follows:

$$
\mathrm{ET}=\mathrm{T}+\mathrm{E}
$$

where $T$ is the estimated crop ET, and $E$ is the estimated surface evaporation. The crop ET, in turn, is estimated from $\mathrm{ET}_{\mathrm{p}}$ as follows:

$$
T=f K_{c} E_{p}
$$

where $K_{c}$ is a crop coefficient, determined from independent experiments by examining the ratio of $T$ to $\mathrm{ET}_{\mathrm{p}}$ in various growth stages for a well-watered crop. Growth stage was estimated according to the accumulation of GDDs. $K_{\mathrm{c}}$ values were also specified according to the accumulation of GDDs.

The factor $f$ is a ratio of the actual to potential ET that depends on available soil water content (Baier, 1969). Hubbard (1992) explained that the factor $f$ allows the model to simulate transpiration when the crop is not well watered, and $f$ is referred to as a soil water reduction factor. For determining optimal crop water requirements, $f$ was taken as 1.0 and soil evaporation $E$ was considered negligible.

Estimating seasonal ET in the model also required information on GDDs and emergence date for crops. GDDs are a numerical expression of the relationship between plant growth and development and the atmospheric temperature. Neild and Seeley (1977) reviewed various methods for GDD calculations and concluded that the most practical and simple method is based on temperature: GDDs are calculated as the sum of differences between daily mean temperatures and the base temperature for each day after a given starting date. The base temperature is a threshold value above which plants develop during a particular phase (Aceves-Navarro, 1987). In Nebraska, the temperature pattern decreases from southeast to north- 
west. Variations between locations, between seasons at a particular location, between planting times, and between the requirements of different hybrids contribute to the large differences in the number of days it takes for a crop to mature (Neild, 1986). In this study, locations of the crop-growing regions in Nebraska were defined based on work by Neild (1986), Aceves-Navarro (1987), and Benham (1998). The seasonal ET values, calculated by this approach, are for well-watered crops, which is reasonable for corn, sorghum, and soybean because these crops are grown in the higher rainfall areas of the state. For wheat and grass, however, a different approach was required to develop seasonal ET estimates.

\subsection{Estimating seasonal crop moisture thresholds for wheat and grass}

Drought is the most important environmental factor limiting wheat productivity in semiarid regions of the world (Ehdaie, 1995). In 1997, 95\% of all wheat crops in Nebraska were harvested from rainfed cropland. Most of the counties leading in wheat production are located in the semiarid climate of western $\mathrm{Ne}-$ braska (NASS, 1998). Grain yield under drought is dependent on many phenological, morphological, and physiological characteristics of wheat. WUE is considered an important physiological characteristic involved in adaptation of wheat to drought.

WUE is the weight of grain produced for each unit volume of water used. Musick and Porter (1990) define WUE as grain yield per unit of seasonal ET. When WUE and yield data are available, ET can be calculated as follows:

$$
\mathrm{ET}=\text { Yield } / \mathrm{WUE}
$$

WUE can be expressed in units of $\mathrm{kg} \mathrm{m}^{-3}$. The WUE of field crops has increased considerably over the past 50 years, largely because of the development of higher-yielding cultivars rather than reduced water use (Adam, 1989; Musick and Porter, 1990). At the present time, WUE ranges from 0.8 to $1.2 \mathrm{~kg} \mathrm{~m}^{-3}$ (Miller, 1977; Musick et al., 1984; Adam, 1989; Musick and Porter, 1990). WUE values for Nebraska wheat used in this approach were acquired from the studies by Klinkebiel (1987) and Adam (1989) conducted in Nebraska. In the southeastern portion of the state, wheat is grown without irrigation. In central and western Nebraska, wheat is grown predominantly on dryland with a small percentage irrigated (NASS, 1998). Several studies investigated differences between the WUEs of dryland and irrigated wheat. Musick et al. (1984) found that WUE of dryland wheat averaged about one-half of the WUE of irrigated wheat grown over a wide range of water deficits. Klinkebiel (1987) found WUEs for wheat to be very similar across rainfed, medium irrigation, and full irrigation treatments. Adam (1989) found an increase in WUE with the increase of the water level applied. WUE of wheat measured by Adam (1989) for wheat fallow treatments at Sidney, Nebraska, ranged from 0.7 to $0.8 \mathrm{~kg} \mathrm{~m}^{-3}$.

Based on wheat WUE values reported in the literature, it was estimated that WUE of rainfed wheat in southeastern Nebraska is about $0.7 \mathrm{~kg} \mathrm{~m}^{-3}$. In central Nebraska, WUE of wheat (mostly rainfed) is about $0.8 \mathrm{~kg} \mathrm{~m}^{-3}$; in western Nebraska, WUE of rainfed and irrigated wheat cultivars is about $0.9 \mathrm{~kg} \mathrm{~m}^{-}$ 3. Wheat yield data were obtained from the Nebraska Natural Resources database (NASS, 1997; NRC, 1999). The historical wheat yield data (1967-97) were analyzed for three sample counties located in western, central, and eastern Nebraska. Box Butte, Lincoln, and Gage Counties (see Figure 1) were selected for the analysis because of high wheat production in recent years. In 1997, these counties harvested more than 12,140 ha of wheat. The statistical distribution of 30 years of annual grain yield harvested per hectare (Figures $5 a, b, c)$ showed a wide range of yields in all of the selected counties. The highest yield, $3.1 \mathrm{t} \mathrm{ha}^{-1}$, was harvested in Gage County. The lowest yield, $1.3 \mathrm{t} \mathrm{ha}^{-1}$, was harvested in Box Butte County. The median yields were $2.5 \mathrm{t} \mathrm{ha}^{-1}$ in Gage and Lincoln Counties and $2.3 \mathrm{t} \mathrm{ha}^{-1}$ in Box Butte County.

The lower yields in the left tail of the yield distribution indicate the least desirable yields for wheat farmers. In general, farm failures are higher in those years when the yields are lowest. We make the following assumption to define a threshold yield. If the yields in the lowest one-third of the yield distribution could be raised to the threshold separating the lower third from the middle third, the economic success and sustainability would be greatly improved. This threshold, $Y_{1 / 3}$ (one-third of the yield distribution), and wheat WUE were used to estimate a threshold seasonal $\mathrm{ET}_{\mathrm{s}}$ for wheat crops. 
(a)

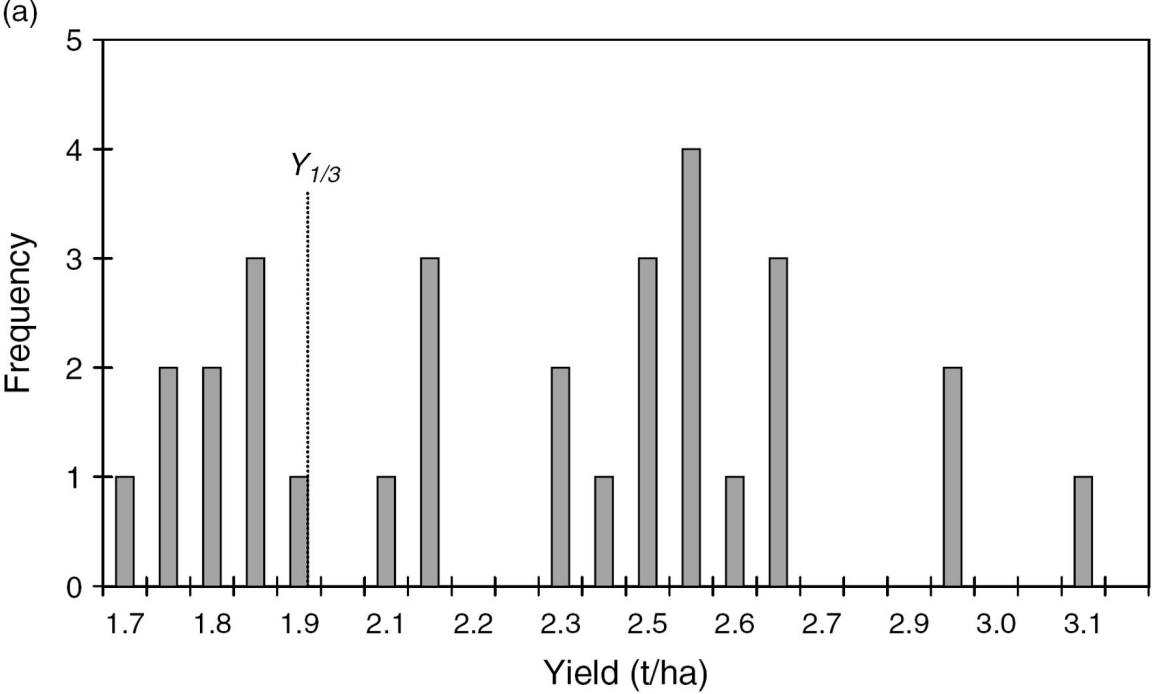

(b)

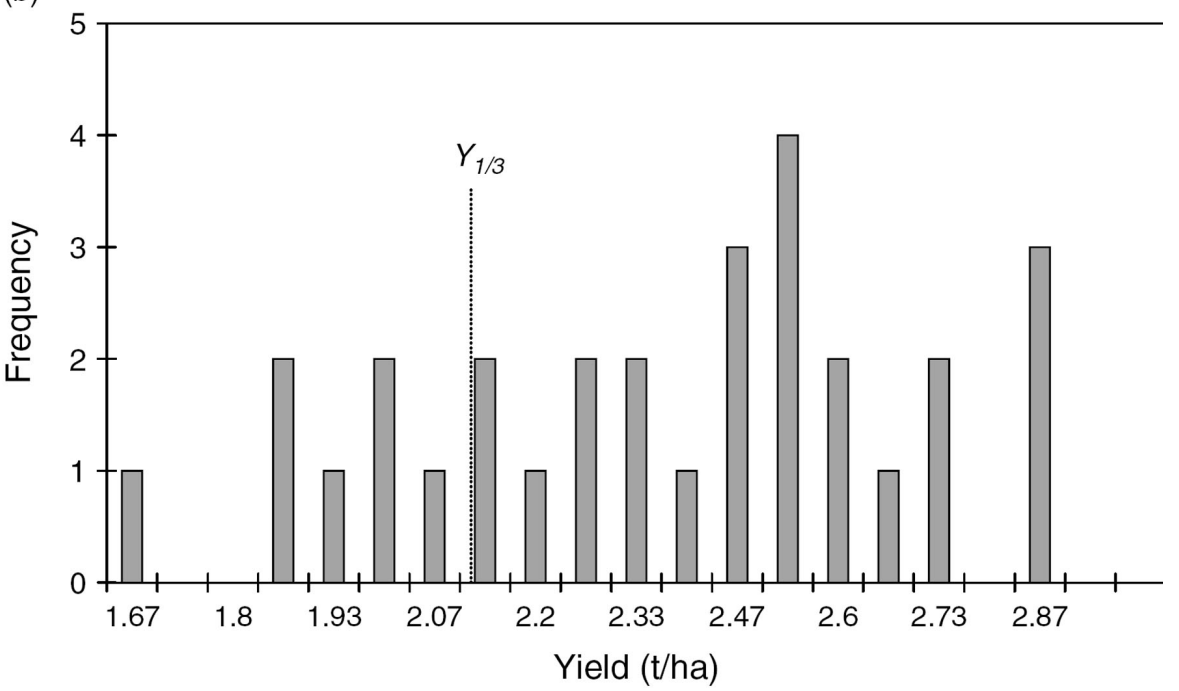

(c)

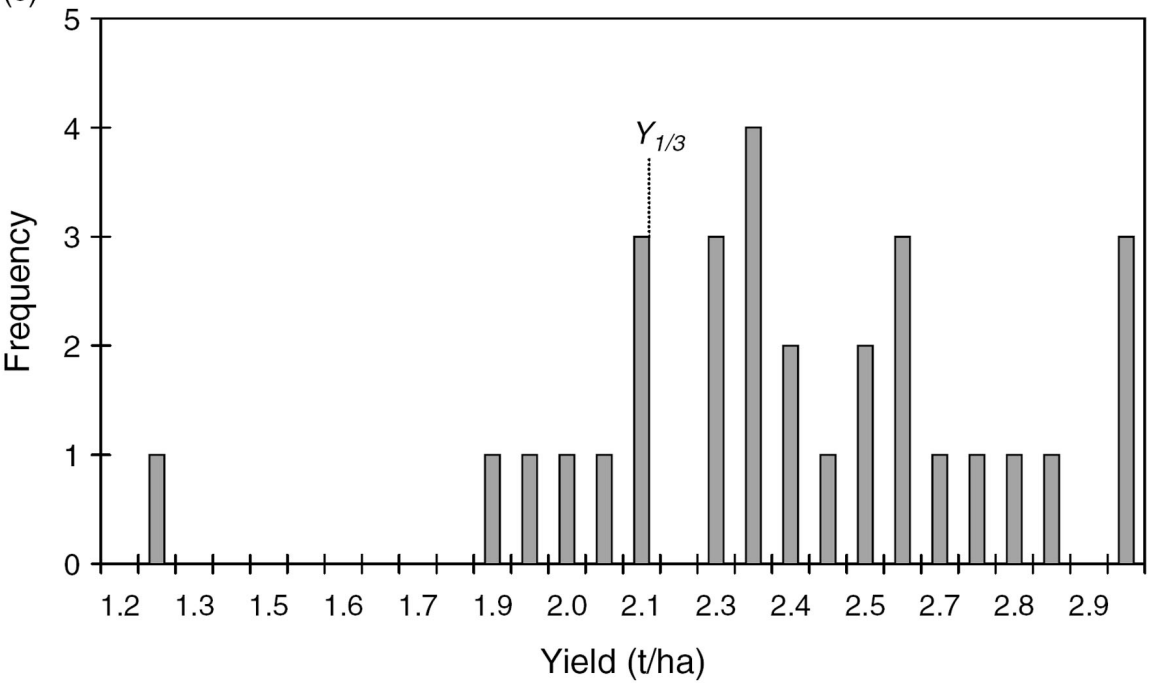

Figure 5. Statistical distribution of wheat yield from 1967 to 1997 for (a) Gage, (b) Lincoln, and (c) Box Butte Counties. $Y_{1 / 3}$ shows the lowest one-third of total yield range 


\subsection{Estimating area-weighted mean $\mathrm{ET}_{\text {s }}$ for combination of crops in a county}

For further spatial analysis of seasonal crop moisture requirements, the following steps were taken. First, county crop statistics data obtained from Nebraska Agricultural Census (NASS, 1997) were analyzed to calculate the percent of each crop area compared to total cropland acreage harvested in a county. Second, the county crop acreage data, information on GDD regions, outputs of the ET model (Hubbard, 1992), and the results of Equation (2) were used to calculate the seasonal crop moisture requirements for the combination of crops in a county. The following formula was used to calculate the area-weighted mean $\mathrm{ET}_{\mathrm{s}^{\prime}}\left(\overline{\mathrm{ET}}_{\mathrm{s}}\right)$ :

$$
\overline{\mathrm{ET}}_{\mathrm{s}}=\frac{\mathrm{ET}_{\mathrm{s}, \mathrm{c}} p_{\mathrm{c}}+\mathrm{ET}_{\mathrm{s}, \mathrm{w}} p_{\mathrm{w}}+\mathrm{ET}_{\mathrm{s}, \mathrm{sb}} p_{\mathrm{sb}}+\mathrm{ET}_{\mathrm{s}, \mathrm{srg}} p_{\mathrm{srg}}+\mathrm{ET}_{\mathrm{s}, \mathrm{g}} p_{\mathrm{g}}}{p_{\mathrm{c}}+p_{\mathrm{w}}+p_{\mathrm{sb}}+p_{\mathrm{srg}}+p_{\mathrm{g}}}
$$

where the subscripts c, w, sb, srg, and g represent corn, wheat, soybean, sorghum, and grass respectively, and $p$ is the portion of land under a given crop compared with total cropland in a county.

\subsection{Calculating probability of seasonal crop moisture deficiency}

Statistical probabilities of seasonal crop moisture deficiency were calculated using SAS Statistical Software (SAS Institute Inc., Cary, NC). Test results with respect to normality (PROC UNIVARIATE) for the nine weather stations with 100 years of rainfall data showed that Alliance West, Bridgeport, Broken Bow, and West Point had a normal seasonal (April-September) rainfall distribution. Seasonal rainfall data at Ainsworth and Hartington were close to normal, and the growing season precipitation at Imperial, Red Cloud, and Tecumseh was not normally distributed. Since the normality test did not show uniform normal distribution for seasonal precipitation across Nebraska, statistical probabilities were calculated by the empirical cumulative distribution function (CDF).

\subsection{Spatial interpolation}

The values of statistical probabilities of seasonal moisture deficiency were assigned to the weather stations' point coverage using ArcView GIS (Environmental Systems Research Institute Inc., Redlands, CA). Since measured climatological variables are not available at every location in the study area, sample input point locations (112 weather stations) were used to interpolate the original values to form estimates on an evenly spaced grid. An additional ten weather stations in the neighboring states were used to ensure interpolation instead of extrapolation near the state border. The surface interpolators make certain assumptions about how to determine the best-estimated value. In this study we used the Spline interpolator in ArcView Spatial Analyst (ESRI, Inc.).

Spline is a general-purpose interpolation method that fits a minimum-curvature surface through the input points. It fits a mathematical function to a specified number of nearest input points while passing through the sample points. This method is best for gently varying surfaces, such as elevation, water table heights, or pollution concentrations, and is often used to interpolate climatological variables. The "tension" method, which tunes the stiffness of the surface according to the character of the phenomenon modeled, was used in this study. The weight of "tension" was set to 150, and the number of points per region used for local approximation was set to 12 . The output grid was at $200 \mathrm{~m}$ spatial resolution. The grid was classified into four classes. Probability of seasonal crop moisture deficiency less than $30 \%$ was classified as "low"; between 30 and 50\%, "moderate"; between 50 and 70\%, "high"; and more than 70\%, "very high".

\subsection{Integrated assessment}

The methodology for integrated assessment of agricultural drought vulnerability is presented in Wilhelmi and Wilhite (2002). To produce an agricultural drought vulnerability map, the probability of seasonal crop moisture deficiency was combined in the ERDAS Imagine GIS with data layers of soil root zone available water-holding capacity, land-use types, and irrigated cropland to determine the areal extent of 
combinations of classes present. A numerical weighting scheme was used to assess the drought vulnerability potential of each factor. All GIS data layers were co-registered with their respective cell coordinates. The derived classes of the drought vulnerability map were based on the numerical weights, informed judgment and the analysis of the combined input variables.

\section{Results and Discussion}

The input variables used in the ET model (Hubbard, 1992) and the estimated seasonal ET for well-watered crops (e.g. corn, soybean, and sorghum) are given in Table I for the sample locations in Nebraska. The results of the model showed that total seasonal water use for corn ranges from around $520 \mathrm{~mm}$ in western Nebraska to around $630 \mathrm{~mm}$ in eastern Nebraska. The differences in seasonal water use (or ET) for different locations are due to differences in the number of days that it takes for the crop to mature. Longer-season corn varieties use more water, but they also produce more grain if the temperature and moisture conditions are favorable. Sorghum and soybean varieties require less water and, compared with corn, have shorter growing seasons.

The input variables used to calculate seasonal water use for wheat (Equation (2)), wheat's growing requirements, and the estimated seasonal $\mathrm{ET}_{\mathrm{s}}$ are presented in Table II for three sample locations in eastern, central, and western Nebraska. The $\mathrm{ET}_{\mathrm{s}}$ values show the amount of water that is needed for the crop, below which the wheat producers experience lower yields and greater vulnerability. Wheat $\mathrm{ET}_{\mathrm{s}}$ values also vary across the state, decreasing from east to west. Compared with crops in the higher rainfall areas, it was estimated that wheat requires less seasonal moisture. The $\mathrm{ET}_{\mathrm{s}}$ values for rangeland grasses were similar to those for wheat and ranged from $244 \mathrm{~mm}$ to $274 \mathrm{~mm}$ in western and eastern Nebraska respectively.

Most Nebraska counties, with the exception of the Sand Hills region (in the north-central portion of the state), where grassland is dominant, are diverse mosaics of various crops. Especially diverse cropland patterns are located in the southeastern portion of the state. Table III illustrates the calculations of $\overline{\mathrm{ET}}_{\mathrm{s}}$ (Equation (3)) for three sample locations. Calculated $\overline{\mathrm{ET}}_{\mathrm{s}}$ values were then assigned to the weather stations with long-term precipitation records located in the corresponding counties. A map showing the geographical distribution of $\overline{\mathrm{ET}}_{\mathrm{s}}$ in Nebraska is given in Figure 6.

Table I. GDD requirements and seasonal crop water use $\left(\mathrm{ET}_{\mathrm{s}}\right)$ for well-watered crops in Nebraska

\begin{tabular}{llllcc}
\hline Crop & Weather station & Base $T\left({ }^{\circ} \mathrm{C}\right)$ & GDD & Emergence date & Estimated ET $(\mathrm{mm})$ \\
\hline Corn & Mead, NE & 10 & 3000 & $4-25$ & 628 \\
Corn & Lexington, NE & 10 & 2500 & $5-5$ & 572 \\
Corn & Scotts Bluff, NE & 10 & 1900 & $5-15$ & 526 \\
Soybean & Mead, NE & 10 & 2700 & $5-10$ & 479 \\
Soybean & Ord, NE & 10 & 2000 & $5-20$ & 358 \\
Sorghum & Beatrice, NE & 10 & 2700 & $5-10$ & 483 \\
Sorghum & McCook, NE & 10 & 2025 & $5-20$ & 394 \\
\hline
\end{tabular}

Table II. Wheat growing requirements, water use efficiency, threshold yield, and estimated $\mathrm{ET}_{\mathrm{s}}$ values for three sample locations in Nebraska

\begin{tabular}{lccccccc}
\hline Weather station & $\begin{array}{c}\text { Base } T \\
\left({ }^{\circ} \mathrm{C}\right)\end{array}$ & GDD & $\begin{array}{c}\text { Emergence } \\
\text { date }\end{array}$ & $\begin{array}{c}\text { WUE } \\
\left(\mathrm{kg} \mathrm{m}^{-3}\right)\end{array}$ & County & $\begin{array}{c}Y_{1 / 3} \begin{array}{c}\text { Estimated } \\
\left(\text { ton ha }^{-1}\right)\end{array} \\
\mathrm{ET}_{\mathrm{s}}\left(\mathrm{mm}^{2}\right.\end{array}$ \\
\hline Beatrice & 4.4 & 2550 & $3-15$ & 0.7 & Gage & 1.93 & 274 \\
Dickens & 4.4 & 2550 & $3-20$ & 0.8 & Lincoln & 2.09 & 261 \\
Alliance (west) & 4.4 & 1930 & $3-15$ & 0.9 & Box Butte & 2.13 & 244 \\
\hline
\end{tabular}




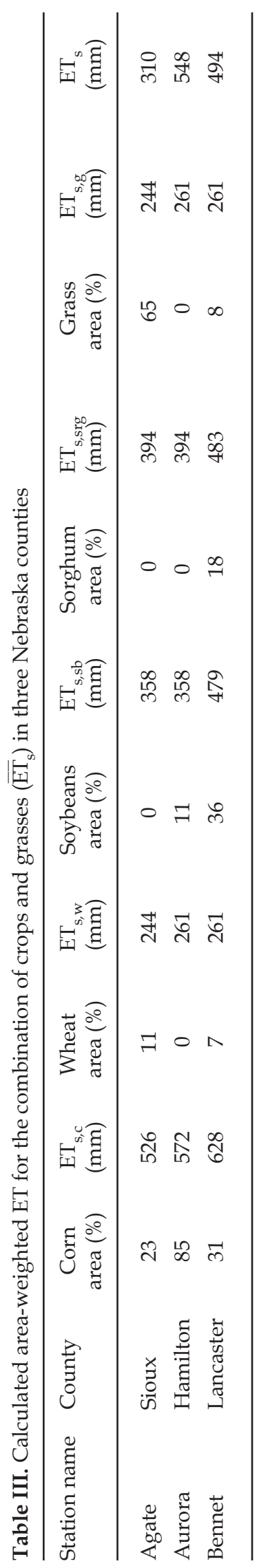




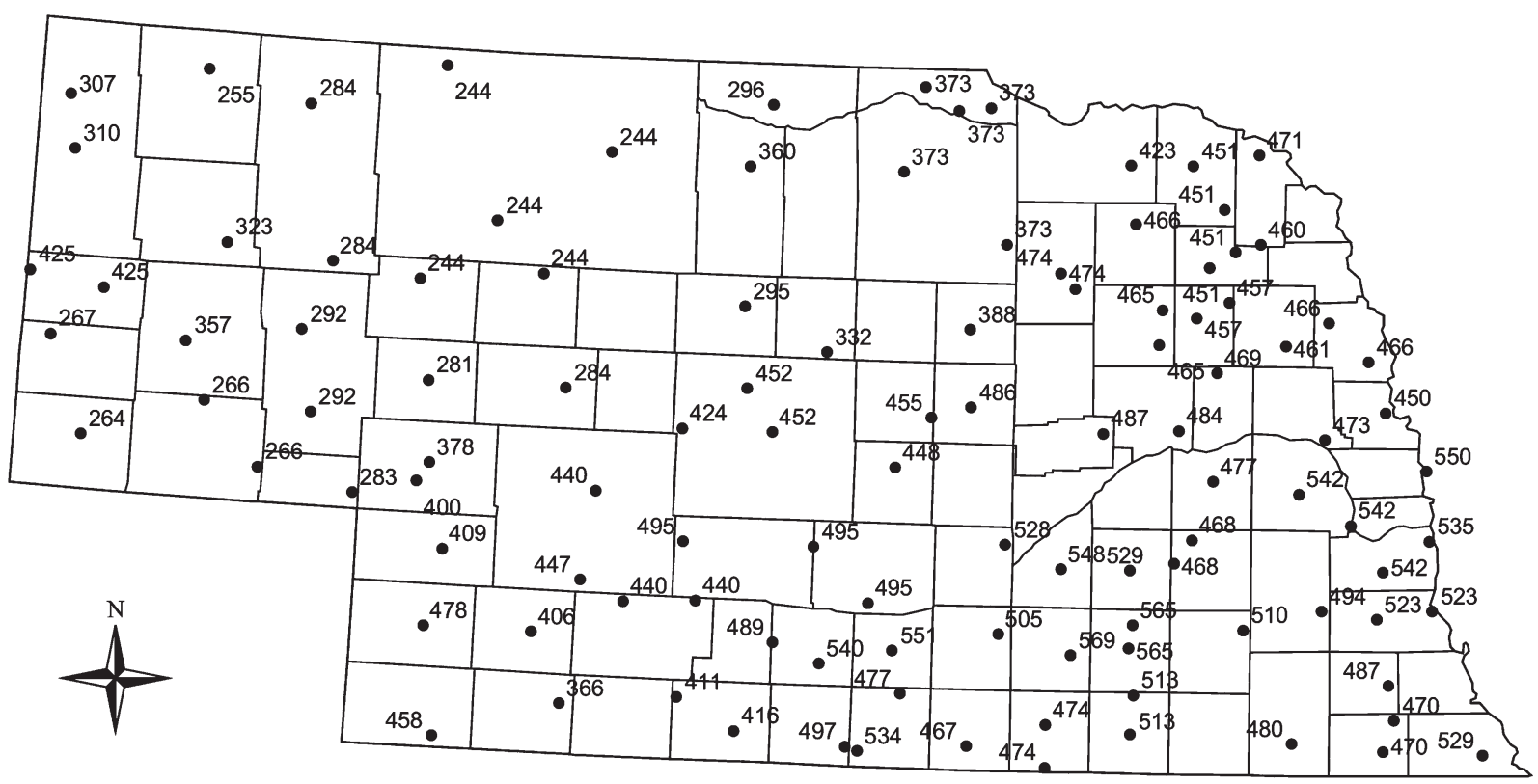

Figure 6. Calculated area-weighted mean seasonal ET $(\mathrm{mm})$ for the combination of crops and grasses in Nebraska counties

Statistical probabilities of seasonal crop moisture deficiency were estimated by a CDF using the SAS statistical software (Figure 7). The probabilities of seasonal crop moisture deficiency range from as low as $2 \%$ in the Sand Hills rangelands up to $92 \%$ in Scotts Bluff County in western Nebraska, where $61 \%$ of the cropland is under corn for grain. The final map with the results of spatial interpolation and classification is presented in Figure 8.

It is important to mention that since the irrigation data layer was introduced in a separate stage of the GIS analysis (Wilhelmi and Wilhite, 2002), the results of this study show the probability of seasonal crop moisture deficiency as if all crops in Nebraska were rainfed only. Calculated $\overline{\mathrm{E}} \overline{\mathrm{T}}_{\mathrm{s}}$ values reflect seasonal water requirements for the mixture of crops grown in a county. Seasonal crop water requirement for corn

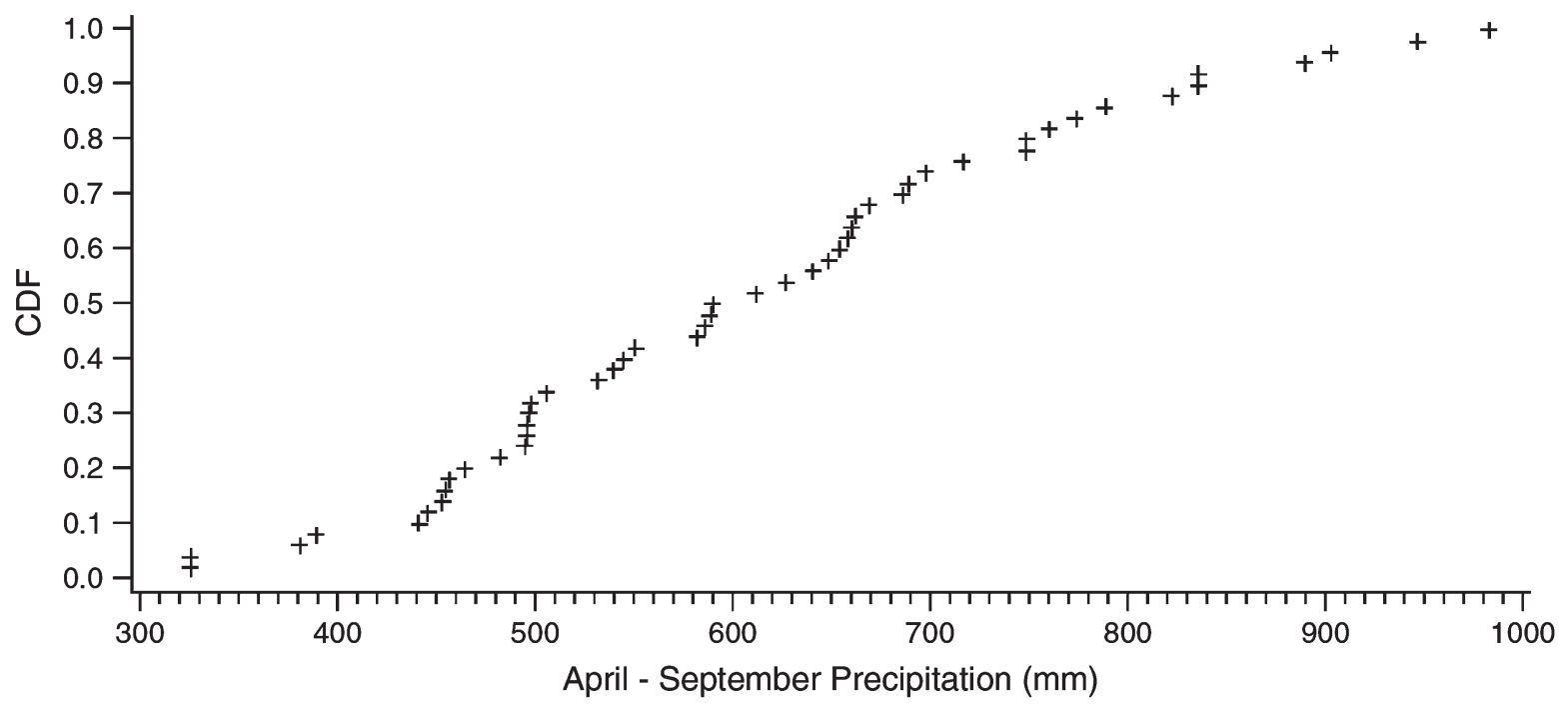

Figure 7. The empirical Cumulative Distribution Function (CDF) for seasonal crop moisture deficiency at Bennet, Nebraska was calculated using seasonal ET threshold $(494 \mathrm{~mm})$ and 50 years (1948-1997) of seasonal precipitation data. Data were plotted using SAS statistical software (SAS Institute, Inc.). 


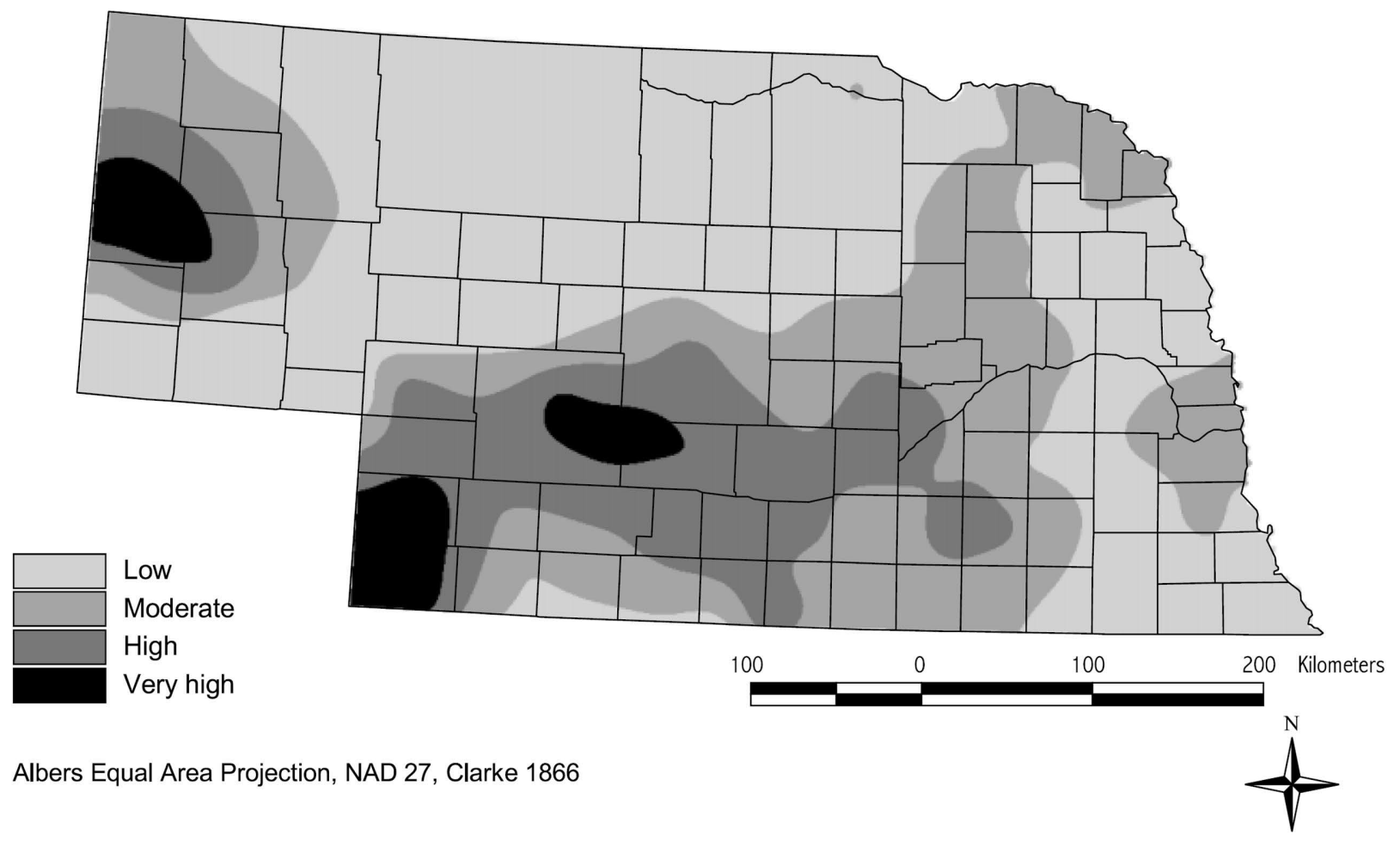

Figure 8. Probability of seasonal crop moisture deficiency in Nebraska. Spatial interpolation was performed using Arc View Spline.

is the largest, compared with other crops (Tables I and II). In counties where corn constitutes a large fraction of total cropland, combined $\overline{\mathrm{E}} \overline{\mathrm{s}}_{\mathrm{s}}$ resulted in relatively high seasonal values. The spatial pattern of statistical probabilities of seasonal crop moisture deficiencies reflects both the seasonal precipitation distribution across the state and the distribution of the crops and grasses.

Increased probability of seasonal moisture deficiency resulted from either a higher fraction of the corn crop grown in the counties, a decreased seasonal precipitation, or a combination of the two. For example, the area of moderate probability of seasonal moisture deficiency shown in eastern Nebraska is mainly in Sarpy, Cass, and Otoe Counties. In all of these counties the fraction of corn is at least $43 \%$ and the fraction of wheat and grass, which requires less seasonal moisture, is smaller than $10 \%$.

Figure 8 also shows that portions of central and western Nebraska do not receive sufficient rainfall for crops more than $50 \%$ of the time, and in extreme cases (e.g. Scotts Bluff, Chase, and Dundy Counties) more than $70 \%$ of the time. High and very high probabilities in these regions are associated with the large fraction of corn, which explains why at least $90 \%$ of the corn in these counties is irrigated (NASS, 1997).

Incorporation of probability of seasonal crop moisture deficiency with other vulnerability factors into a GIS-based assessment resulted in a $200 \mathrm{~m}$ spatial resolution map of agricultural drought vulnerability with classes of low, low-to-moderate, moderate and high vulnerability (Figure 9). The detailed results of this assessment are presented in Wilhelmi and Wilhite (2002).

\section{Concluding Remarks}

In a new approach for spatially representative depiction of the agroclimatological component of drought vulnerability, a seasonal crop moisture deficiency dataset was derived. The approach was based on incorporating long-term precipitation data and thresholds for grown crops into a probability of deficient seasonal moisture, which is critical for crops. The map of probabilities of seasonal crop moisture de- 


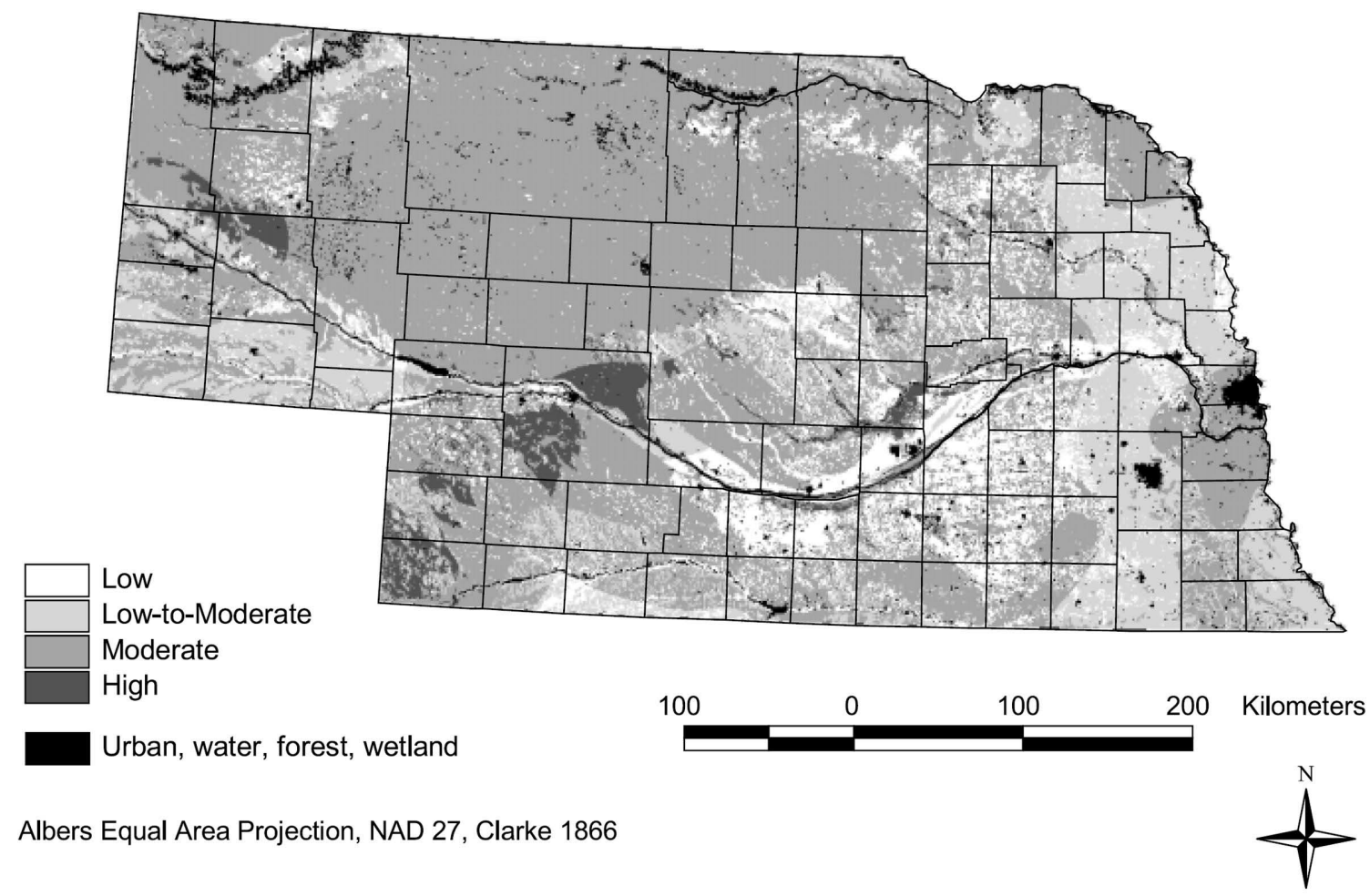

Figure 9. Agricultural drought vulnerability in Nebraska (from Wilhelmi and Wilhite (2002))

ficiency was used in a GIS together with soil root zone available water-holding capacity, land-use types, and irrigated cropland to map agricultural drought vulnerability.

We realize that crop thresholds and interpolation methods may vary depending on the regional characteristics. However, the conceptual framework of the approach presented brings a new insight on representation of agroclimatology in spatial drought vulnerability assessments and can be of significant value to agriculturalists and policy makers. This methodology could be useful for many drought-prone agricultural regions in the world where crop losses may impact human well-being. The state of Nebraska presented a good case study because of the considerable variation in climatology, soil characteristics, land use, and cropping patterns.

The spatial distribution of the probability of seasonal crop moisture deficiency will be different if changes in cropping patterns occur. Therefore, if used on an operational basis for drought risk and vulnerability assessment, the crop-climate database will need to be updated periodically as the distribution of crops changes in response to economic factors, climate trends, and government programs.

\section{Acknowledgments}

The work reported here was conducted under Nebraska Agricultural Research Division Project 27-007. Dr. Michael Hayes and the anonymous reviewer for International Journal of Climatology provided insightful comments to an earlier version of this paper.

\section{References}

Aceves-Navarro LA. 1987. Agroclimatic procedures related to crop production in the north central region of the U.S.A. Ph.D. dissertation, Department of Horticulture and Forestry, University of Nebraska-Lincoln, Lincoln, NE.

Adam NR. 1989. The effect of water level, cropping system and tillage on yield, yield components and water-use Efficiency of wheat and sorghum. MS Thesis, Department of Agronomy, University of Nebraska-Lincoln, Lincoln, NE. 
Baier W. 1969. Concepts of soil moisture availability and their effects on soil moisture estimates from a meteorological budget. Agricultural Meteorology 6: 165-178.

Benham BL. 1998. Irrigating corn. In NebGuide, G98-1354-A. INAR-University of Nebraska-Lincoln.

Changnon SA, Kunkel KE. 1999. Rapidly expanding uses of climate data and information in agriculture and water resources: causes and characteristics of new applications. Bulletin of the American Meteorological Society 80: 821-830.

Choudhury PN, Kumar V. 1980. The sensitivity of growth and yield of dwarf wheat to water stress at three growth stages. Irrigation Science 1: 223-231.

Dale RF, Shaw RH. 1965. Effect on corn yields of moisture stress and stand on two fertility levels. Agronomy Journal 57: 475-479.

Downing TE, Bakker K. 2000. Drought discourse and vulnerability. In Drought: A Global Assessment, Natural Hazards and Disasters Series, vol. II, Wilhite DA (ed.). Routledge Publishers: UK; chapter 45.

Eastman JR, Emani S, Hulina S, Jiang H, Johnson A, Ramachandran M (eds.). 1997. Application of geographic information systems (GIS) technology in environmental risk assessment and management. Idrisi Project, Clark University: Worcester, MA.

Ehdaie B. 1995. Variation in water-use efficiency and its components in wheat: pot and field experiments. Crop Science 35: 1617-1626.

Felch RE. 1978. Drought: characteristics and assessment. In North American Droughts, Rosenberg NJ (ed.). AAAS Selected Symposia Series. Westview Press: 25-42.

Hayes, MJ. 1999. Drought indices. URL (accessed July 26, 2002): http://enso.unl.edu/ndmc/enigma/indices.htm

Hubbard KG. 1992. Climatic factors that limit daily evapotranspiration in sorghum. Climate Research 2: 73-80.

Kincaid DC, Hermann DF. 1974. Scheduling irrigations using a programmable calculator. USDA-ARS-NC-12. Washington, DC.

Klinkebiel DL. 1987. Evaluation of crop water-use efficiencies in western Nebraska. MS Thesis, Department of Agronomy, University of Nebraska-Lincoln, Lincoln, NE.

Klocke NK, Hubbard KG, Kranz WL, Watts DG. 1990. Evapotranspiration (ET) or crop water use. In NebGuide, G90992-A. INAR - University of Nebraska-Lincoln.

Krimsky S, Plough A. 1988. Environmental Hazards: Communicating Risks as a Social Process. Auburn House: Dover, MA.

Le Houerou HN. 1996. Climate change, drought and desertification. Journal of Arid Environments 34: 133-185.

McKee TB, Doesken NJ, Kleist J. 1993. The relationship of drought frequency and duration to time scales. In 8 th Conference on Applied Climatology, 17-22 January, Anaheim, CA; 179-184 (preprints).

Miller DE. 1977. Deficit high-frequency irrigation of sugar beets, wheat, and beans. In Proceedings of the Conference Water Management for Irrigation and Drainage. American Society of Civil Engineers, Reno, NV; 269-282.

Musick JT, Porter KB. 1990. Wheat. In Irrigation of Agricultural Crops, Stewart BA, Nielson DR (eds.). American Society of Agronomy Inc., Crop Science Society Inc., Soil Science Society Inc.: Madison, WI, USA; 597-638.

Musick JT, New LL, Dusek DA. 1976. Soil water depletion-yield relationships of irrigated sorghum, wheat and soybean. Transactions American Society of Agricultural Engineers 19: 489-493.

Musick JT, Dusek DA, Mathers AM. 1984. Irrigation water management of winter wheat. In ASAE Paper 84-2094. American Society of Agricultural Engineers: St Josef, MI.

NASS (National Agricultural Statistic Service). 1997. 1997 Census of Agriculture. United States Department of Agriculture. URL (accessed July 25, 2002): http://www.nass.usda.gov/census/census97/profiles/ne/ne.htm

NASS (National Agricultural Statistic Service). 1998. Nebraska Agricultural Statistics 1997-1998. Nebraska Department of Agriculture, USDA National Agricultural Statistics Service.

Neild RE. 1986. Growing degree day requirements and freeze risk as a guide to selecting and planting corn hybrids. In NebGuide, G86-796. IANR - University of Nebraska-Lincoln.

Neild RE, Seeley MW. 1977. Growing degree days predictions for corn and sorghum development and some applications to crop production in Nebraska. Nebraska Agricultural Experiment Station Research Bulletin 280.

NRC (Natural Resources Commission). 1999. Nebraska Natural Resources Commission. URL (accessed December 1999): http://www.nrc.state.ne.us/docs/frame4.html

Palmer WC. 1965. Meteorological drought. Research paper no. 45, US Department of Commerce Weather Bureau, Washington, DC.

Penman HL. 1948. Natural evaporation from open water, bare soil and grass. Proceedings of the Royal Society of London 193: $120-145$. 
Ramachandran M. 1997. Risk assessment: a case study of the Ethiopian famine of 1984. In Application of Geographic Information Systems (GIS) Technology in Environmental Risk Assessment and Management, Idrisi Project, Clark University: Worcester, MA; chapter 4.

Ramachandran M, Eastman JR. 1997. Applications of GIS to vulnerability mapping: a West African food security case study. In Application of Geographic Information Systems (GIS) Technology in Environmental Risk Assessment and Management, Idrisi Project, Clark University: Worcester, MA; chapter.

Retta A, Hanks RJ. 1980. Corn and alfalfa production as influenced by limited irrigation. Irrigation Science 1: 135-147.

Riebsame WE, Changnon Jr. SA, Karl TR. 1991. Drought and Natural Resources Management in the United States. Impacts and Implications of the 1987-89 Drought. Westview Press Inc.: Boulder, CO.

Rind D, Goldberg R, Hansen J, Rosenzweig C, Ruedy R. 1990. Potential evapotranspiration and the likelihood of future drought. Journal of Geophysical Research 95(D7): 9983-10 004.

Robinson JM, Hubbard KG. 1990. Soil water assessment for several crops in the High Plains. Agronomy Journal 82: 1141-1148.

Rosenberg MJ, Blad BL, Verma SB. 1983. Microclimate: The Biological Environment. Wiley-Interscience, John Wiley \& Sons: New York.

Shafer BA, Dezman LE. 1982. Development of a surface water supply index (SWSI) to assess the severity of drought conditions in snowpack runoff areas. In Proceedings of the Western Snow Conference; 164-175.

Steila D. 1983. Quantitative vs qualitative drought assessment. Professional Geographer 5: 192-194.

Stockton CW, Meko DM. 1983. Drought recurrence in the Great Plains as reconstructed from long-term tree-ring records. Journal of Climatology and Applied Meteorology 22: 17-29.

Thiruvengadachari S, Gopalkrishna HR. 1993. An integrated PC environment for assessment of drought. International Journal of Remote Sensing 14: 3201-3208.

Thornthwaite CW. 1948. An approach toward a rational classification of climate. The Geography Review 38: 55-94.

Wilhelmi OV, Wilhite DA. 2002. Assessing vulnerability to agricultural drought: a Nebraska case study. Natural Hazards 25: 37-58.

Wilhite DA. 1981. An analysis of Nebraska's precipitation climatology, with emphasis on the occurrence of dry conditions. Miscellaneous Publication 42. Agricultural Experiment Station, University of Nebraska-Lincoln.

Wilhite DA. 2000. Drought as a natural hazard: concepts and definitions. In Drought: A Global Assessment, Natural Hazards and Disasters Series, vol. I, Wilhite DA (ed.). Routledge Publishers: UK; chapter 1.

Wilhite DA, Glantz MH. 1987. Understanding the drought phenomena: the role of definitions. In Planning for Drought: Towards a Reduction of Societal Vulnerability, Wilhite DA, Easterling WE (eds.). Westview Press: Boulder, CO, USA.

Wilhite DA, Vanyarkho O. 2000. Drought: pervasive impacts of a creeping phenomenon. In Drought: A Global Assessment, Natural Hazards and Disasters Series, Wilhite DA (ed.). Routledge Publishers: UK; chapter 18.

Woodhouse CA, Overpeck JT. 1998. 2000 years of drought variability in the central United States. Bulletin of the American Meteorological Society 79: 2693-2714. 